\title{
Mechanism of post-seismic floods after the Wenchuan earthquake in the upper Minjiang River, China
}

\author{
Ding Hairong ${ }^{1,2}$, Li Yong ${ }^{3, *}$, Shao Chonguian ${ }^{3}$, Lauvence Svirchev $^{4}$, Xu Qiang ${ }^{1,2}$, \\ YAn ZhaOKun ${ }^{3}$, Yan Liang ${ }^{3}$, Ni ShiJun ${ }^{1}$ and Shi Zeming ${ }^{1}$ \\ ${ }^{1}$ State Key Laboratory of Geohazard Prevention and Geoenvironment Protection, Chengdu University of \\ Technology, Chengdu 610059, Sichuan Province, China. \\ ${ }^{2}$ College of Environment and Civil Engineering, Chengdu University of Technology, Chengdu 610059, Sichuan \\ Province, China. \\ ${ }^{3}$ National Key Laboratory of Oil and Gas Reservoir Geology and Exploration, Chengdu University of Technology, \\ Chengdu 610059, Sichuan Province, China. \\ ${ }^{4}$ Chengdu University of Technology, Chengdu 610059, Sichuan Province, China. \\ ${ }^{*}$ Corresponding author. e-mail: liy@cdut.edu.cn
}

MS received 12 January 2016; revised 16 April 2017; accepted 19 April 2017; published online 6 October 2017

By analyzing the multi-year runoff and rainfall data at 15 hydrological stations from 1980 to 2007, as well as monthly runoff data from 1964 to 1984 at the Zipingpu hydrologic station, the relationship between precipitation and runoff has been established and the trend was explored. Based on the catastrophic floods of August 13 and August 18, 2010, characteristics and control factors on the post-seismic floods are summarized. Firstly, the Wenchuan earthquake and rupture zone provides the background for postseismic floods to develop in the upper Minjiang River, which follows a post-seismic disaster-chain pattern: earthquake collapse to landslide debris flows to floods. Secondly, heavy rainfall controlled by the orographically-enhanced precipitation after the Wenchuan earthquake is the trigger factor for the development of devastating post-seismic floods. Thirdly, the post-seismic floods contain high sediment discharge, cause abrupt and severe damages, and have a large of volume and higher frequency.

Keywords. Wenchuan earthquake; Minjiang River; heavy rainfall; post-seismic floods; orographicallyenhanced precipitation.

\section{Introduction}

On May 12, 2008, a major earthquake measuring 8.0 on the Richter scale (Ms 8.0) struck Wenchuan, Longmen Shan area, Sichuan Province, China (hereafter referred as the Wenchuan earthquake), which is characterized by high magnitude, long rupture zone, severe damage, strong and frequent aftershocks (Densmore et al. 2010; Li et al. 2011; Zhou et al. 2011). Because the main disaster area is located in a zone of high mountains with deep valleys and of complex geological structure, the earthquake triggered a large number of collapses, landslides, dammed lakes and other secondary disasters. On September 24, 2008, four months after the Wenchuan earthquake, Beichuan County was attacked by heavy rainfall, which triggered a largescale debris flow that killed more than 40 people and washed away thousands of acres of fertile land and houses (Tie and Tang 2011). On August 13, 
2010 and August 17, 2012, heavy rainfall triggered severe multiple post-seismic floods in the upper reaches of Minjiang River causing huge loss of lives and property (Luo 2011; You et al. 2011). Out of the 5 years since the Wenchuan earthquake, flood disasters occurred in 3 years, repeatedly causing significant hazard to post-disaster reconstruction. As a consequence, post-seismic flood has become one of the most important natural disasters in Sichuan.

Experts have done research on the post-seismic disasters after Kanto earthquake in Japan and the Chi-Chi earthquake in Taiwan, the results showing that large-scale multiple landslides, debris flows and flood disasters are inevitable in parallel with the influence of extreme weather, such as typhoon and heavy rainfall after strong earthquake (Lin et al. 2006). Numerous experts have done copious research on the disaster chain of heavy rain floods, landslides and post-disaster events (Cui et al. 2008; Wang and Cheng 2008; Xu et al. 2010; Tang et al. 2011; Tie and Tang 2011; Ding et al. 2014a; Li et al. 2014; Wang et al. 2015). In this paper, on the basis of data collection for the flood and debris flows of 2010 August in the upper Minjiang River, empirical research methods are used, and the causes and post-seismic development characteristics of mountain flood are analyzed. Citing the August 13 and 18, 2010 devastating floods in the zone, this paper analyzes the relationships among rainfall, runoff and flood, and studies the control factors and the mechanism of the post-seismic flood. The paper provides a scientific basis for post-disaster reconstruction work and a reference for future postseismic flood control and integrated river basin planning.

\section{Hydrological characteristic in the upper Minjiang River}

The Minjiang River originates in the southern part of Minshan Mountain, a tributary of the upper reaches of the Yangtze River, a pass-through river type at the eastern edge of the Tibetan Plateau (Li et al. 2006). The river flows through the Minshan Mountain area, crosses the Longmen Shan, and into the Sichuan Basin. The segment from Dujiangyan city to the upstream source of the river is known as the upper reaches of Minjiang River. It is a typical mountain river, showing the landform of high mountains, deep valleys, steep slopes and swift rivers. The river length is $340 \mathrm{~km}$, with a watershed area of approximately $23 \mathrm{~km}^{2}$ (Li et al. 2007). The average slope ratio of the river course is $7.5 \%$ from the northwest to southeast (Li et al. 2007). There are five tributaries in the upper reaches, including Xiaoxing River, Heishui River, Zagunao River, Yuzixi River, Shouxi River, and all of them are located on the right bank of the Minjiang River. The profile of valley section is steep ' $\mathrm{V}$ ' shape with elevation between 700 and $6253 \mathrm{~m}$. The annual average precipitation is 500 $850 \mathrm{~mm}$ and mean annual runoff is 14.4 billion $\mathrm{m}^{3}$, in which accounting for $75 \%$ of the annual runoff is in the wet period from May to October, while only $25 \%$ is in the dry season from November to April of the following year. The Zipingpu hydrological station is the watershed control station in the Minjiang River (figures 1 and 2).

\section{Correlation between precipitation and runoff in the upper Minjiang River}

The data of runoff used in the paper include annual runoff data at 15 hydrological stations from 1980 to 2007, as well as monthly runoff data station from 1964 to 1984 at the Zipingpu hydrologic station (figure 2). The precipitation data during the period of 1980-2007 come from 21 rainfall stations, and monthly precipitation data from 1964 to 1984 at the Dujiangyan meteorological station (figure 2). Excel software is used to integrate the precipitation, runoff statistical data and to establish relationship between rainfall and runoff.

\subsection{Trend analysis of precipitation and runoff}

The average precipitation at Zipingpu hydrologic station during the period of $1980-2007$ is $1201 \mathrm{~mm}$, the minimum value of $763 \mathrm{~mm}$ appearing in 2007, while the maximum value of $1805 \mathrm{~mm}$ appeared in 1990. The peak precipitation interval is about 2 4 years and the peak precipitation is appearing in 1983, 1990, 1992, 1995 and 2001. The statistical results show that the precipitation is in a downward trend since 1980, decreased by about $300 \mathrm{~mm}$ in 2007, accounting for about $25 \%$ of the average annual precipitation. The inter-annual variation coefficient of precipitation is 0.18 (figure 3 ).

The annual average runoff is 13.26 billion $\mathrm{m}^{3}$ at Zipingpu hydrologic station during the period 1980-2007, which means the converted average runoff depth is $587.4 \mathrm{~mm}$. The minimum annual runoff is 9.87 billion $\mathrm{m}^{3}$, appearing in 2002 with converted runoff depth of $437.4 \mathrm{~mm}$. The 


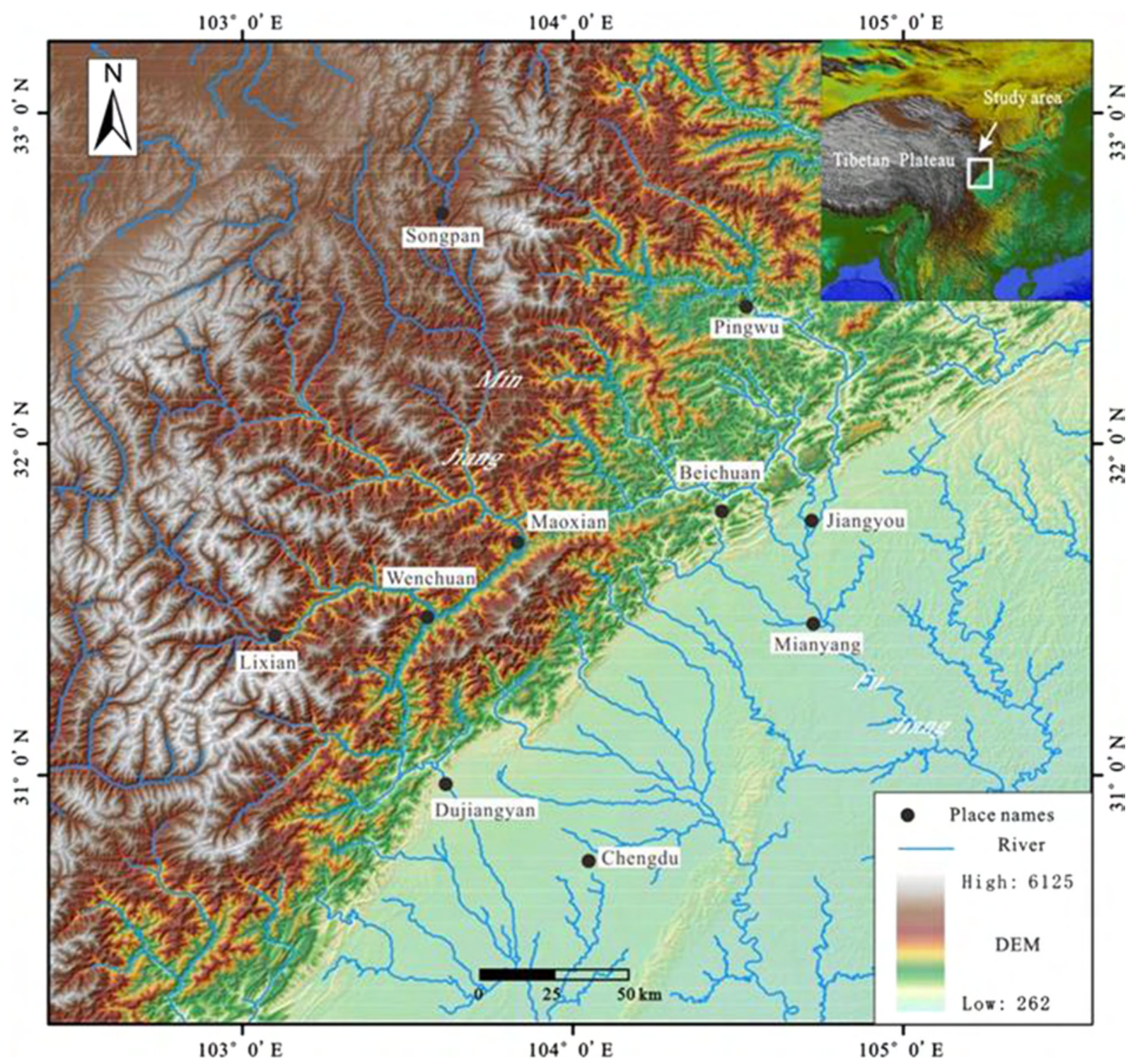

Figure 1. Topography and drainage in the Longmen Shan and Sichuan basin.

maximum value of 15.86 billion $\mathrm{m}^{3}$, appearing in 1992 and converted runoff depth of $702.9 \mathrm{~mm}$. The inter-annual variation coefficient of runoff is 0.11 . The statistical results show that the peak runoff interval is 1-3 years, for example, peak runoff appears in 1981, 1988, 1989, 1990, 1992, 1995, 1998, 1999 and 2001. The peak runoff also shows as a downward tendency. From 1980 to 2007, it decreases by approximately 1.5 billion $\mathrm{m}^{3}$, with converted runoff depth about $44 \mathrm{~mm}$, accounting for about $11 \%$ of the average annual runoff (figure 3). The above statistical results show that in the 27 years before the Wenchuan earthquake, runoff and precipitation are both in a downward trend in the upper Minjiang River, and the variation ration of them is consistent.

\subsection{Correlation between annual precipitation and runoff}

In the upper Minjiang River, precipitation and runoff is of a consistent time trend. The precipitation within May-October accounts for $75-90 \%$ of total annual precipitation (Li et al. 2007, Ding et al. 2013b), while from November to March of the following year, the decreased precipitation accounts for only about $10 \%$ of the year. The distribution of precipitation and runoff is similar, in which the floods occur mainly in the May-October, and concentrate in the July-September periods (figure 4).

The results by correlation of annual precipitation and runoff at Zipingpu hydrological station indicates that the correlation coefficient $R=0.5223$ 


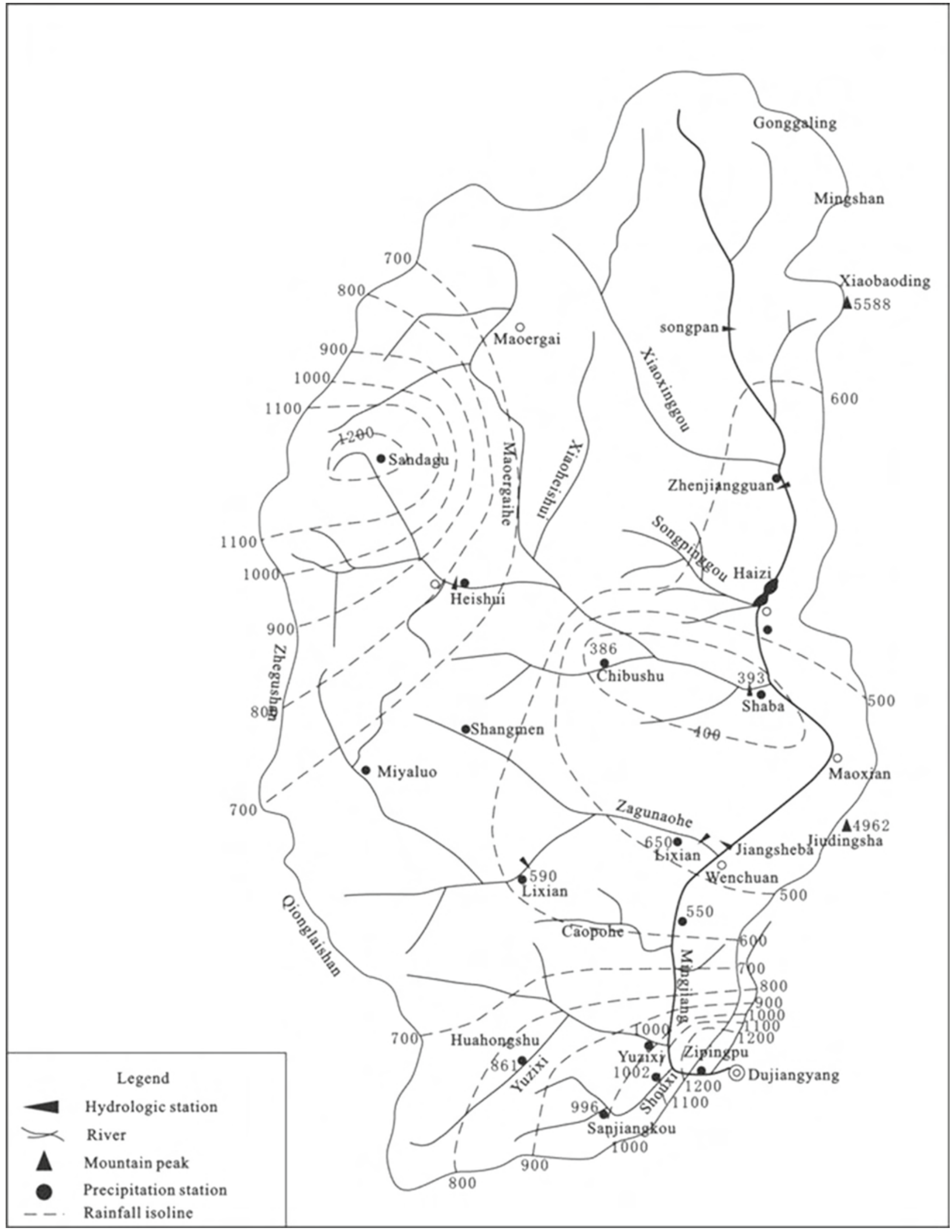

Figure 2. Distribution of rainfall in the upper Minjiang River drainage (Xu 2006). 


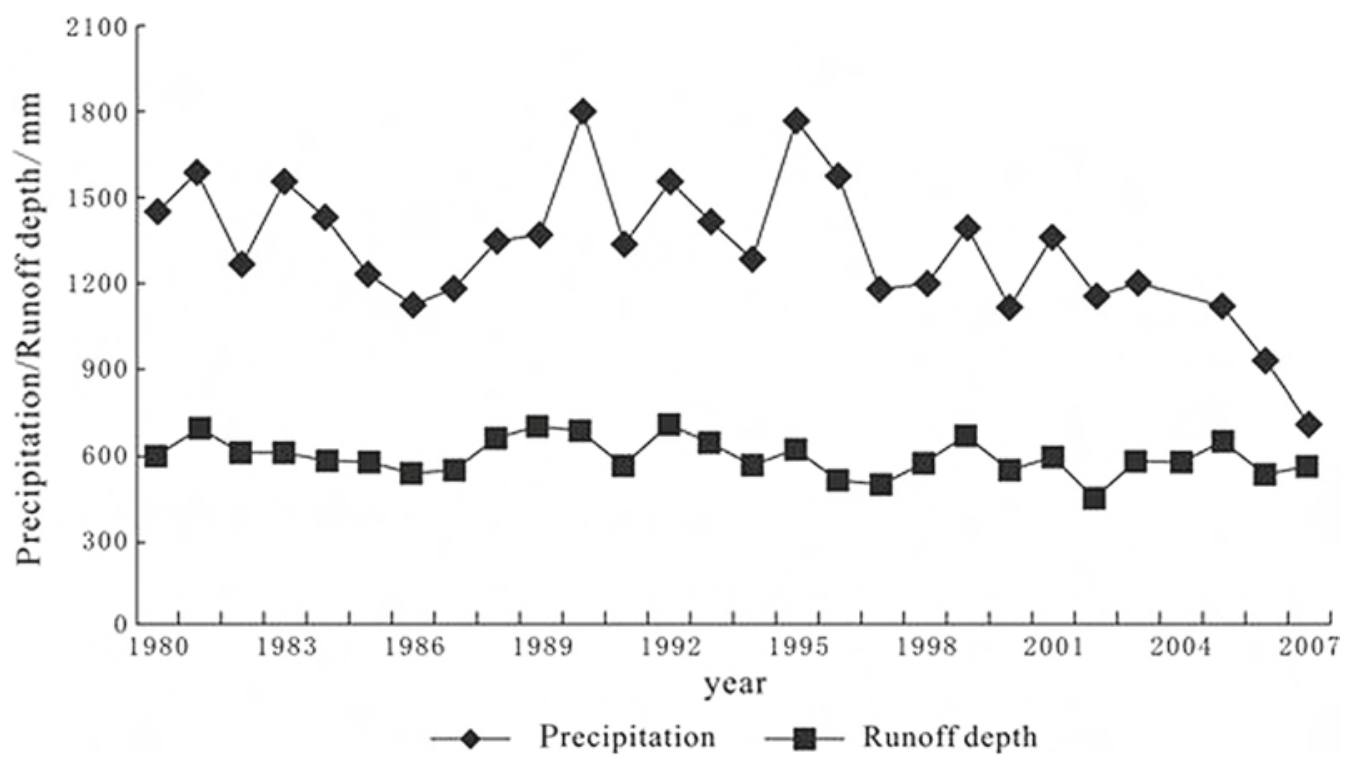

Figure 3. Trend of runoff and precipitation in the upper Minjiang River (1980-2007).

(figure 5), and the annual precipitation and runoff trend are consistent (figure 5). The correlation formula of precipitation and runoff is $Y=0.1436 X+$ 399.47 , which shows that before the Wenchuan earthquake in 2008, the runoff was mainly controlled by precipitation. With the increase of precipitation, runoff was also congruously increased, which indicates that flood is mainly caused by rainfall.

\section{Floods before the Wenchuan earthquake in the upper Minjiang River}

Precipitation in the upper Minjiang River is mainly affected by topography and the southeast monsoon, which varies with season. Rainstorm occurs frequently in wet season, generally during JuneSeptember, especially concentrates in July and August, in which maximum flood peak occurs with the most opportunities. The annual precipitation is also affected by topography. For example, the average annual rainfall in the high mountain zone from Songpan County to Wenchuan is 400-700 mm, while it is $1100-1600 \mathrm{~mm}$ at the foot of the Longmen Shan from Yingxiu of Wenchuan County to Dujiangyan. The measured maximum annual precipitation is $2434.8 \mathrm{~mm}$ at the Zipingpu station in 1947.

\subsection{Inter-annual variation of maximum monthly mean runoff in the upper Minjiang River}

According to peak flow data at the Zipingpu hydrological station (figure 6), the minimum value of monthly mean flow of $700 \mathrm{~m}^{3} / \mathrm{s}$ appeared in 1972. The maximum value appears in 1983, which is $1220 \mathrm{~m}^{3} / \mathrm{s}$ during the flood season from 1964 to 1985. On the whole, the annual flow in flood season trends downward in the region.

\subsection{Inter-annual variation trend of maximum flood peak flow}

The peak flow of disaster flood is greater than $2500 \mathrm{~m}^{3} / \mathrm{s}$ in the upper Minjiang River (Zhang 2006). From 1964 to 1984, most of peak flows at Zipingpu hydrologic station are greater than 2500 $\mathrm{m}^{3} / \mathrm{s}$, and the maximum flood flow is $5840 \mathrm{~m}^{3} / \mathrm{s}$ in 1964 (figure 7). After that, the annual maximum peak flow appears to be in decreasing trend from 1964 to 1984 (figure 7).

According to measured maximum peak flow data of Dujiangyan hydrological station from 1964 to 1984, the peak flow and flood return period are calculated through experience frequency formula $\left(P=\frac{m}{n+1} \times 100 \%\right)$, which refers to table 1 . The results show that from 1964 to 1984, the frequency of flood with return period of 4 years is $32.8 \%$ (whose peak flow is $2500-2750 \mathrm{~m}^{3} / \mathrm{s}$ ), the frequency of flood with return period of 7 years is $13.6 \%$ (whose peak flow is $4000-4300 \mathrm{~m}^{3} / \mathrm{s}$ ), while the frequency of flood with return period of 22 years is $4.5 \%$ (whose peak flow is greater than $4500 \mathrm{~m}^{3} / \mathrm{s}$ ).

\section{Post-seismic floods after the Wenchuan earthquake in the upper Minjiang River}

Many floods and debris flows occurred after the Wenchuan earthquake in the Longmen Shan region 


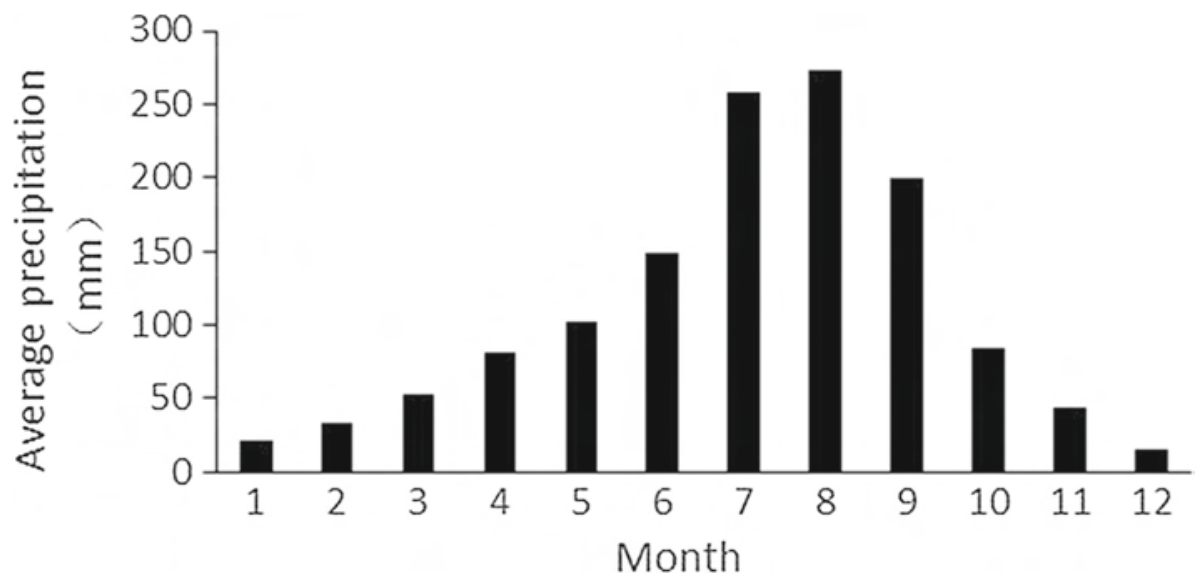

Figure 4. The monthly average precipitation in the upper Minjiang River.

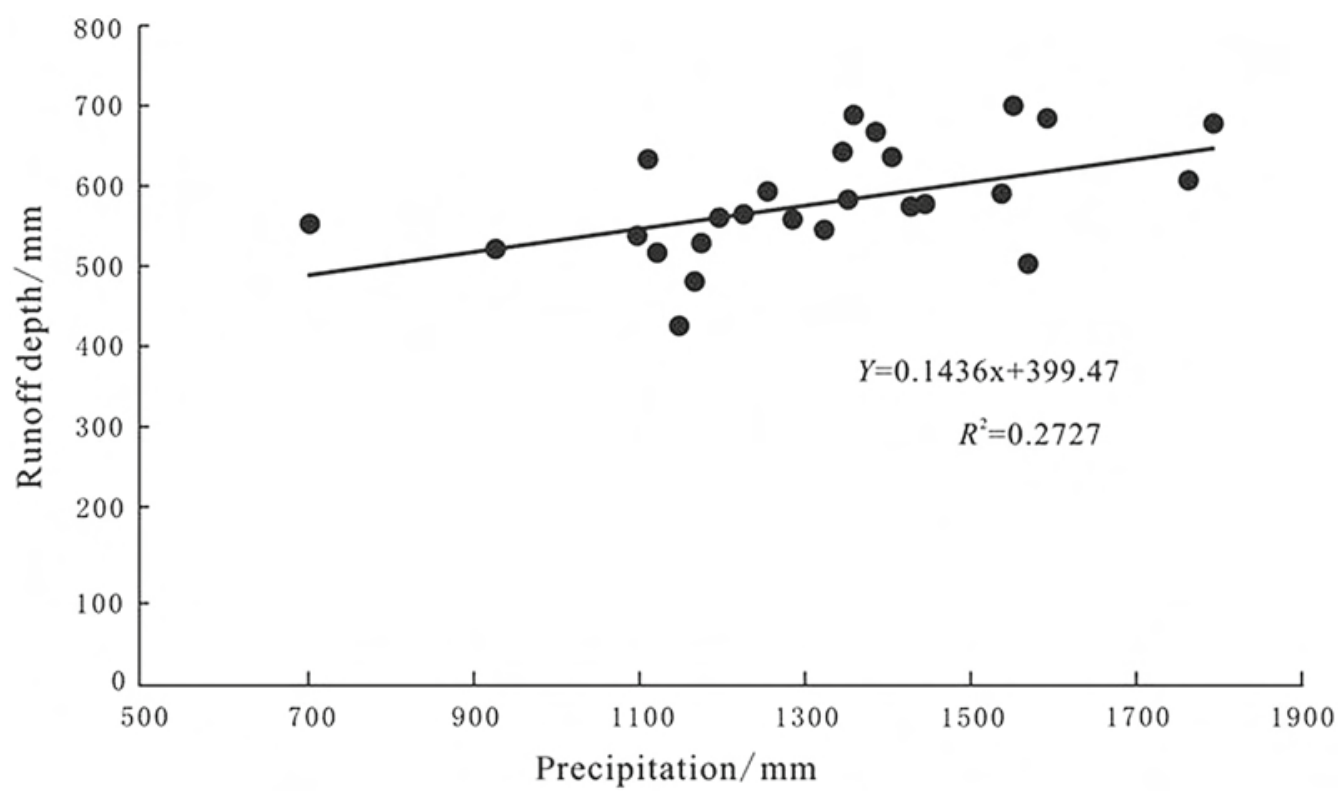

Figure 5. Correlation of precipitation and runoff in the upper Minjiang River.



Figure 6. Maximum monthly mean flow and the corresponding month precipitation (1964-1985) in the upper Minjiang River. 


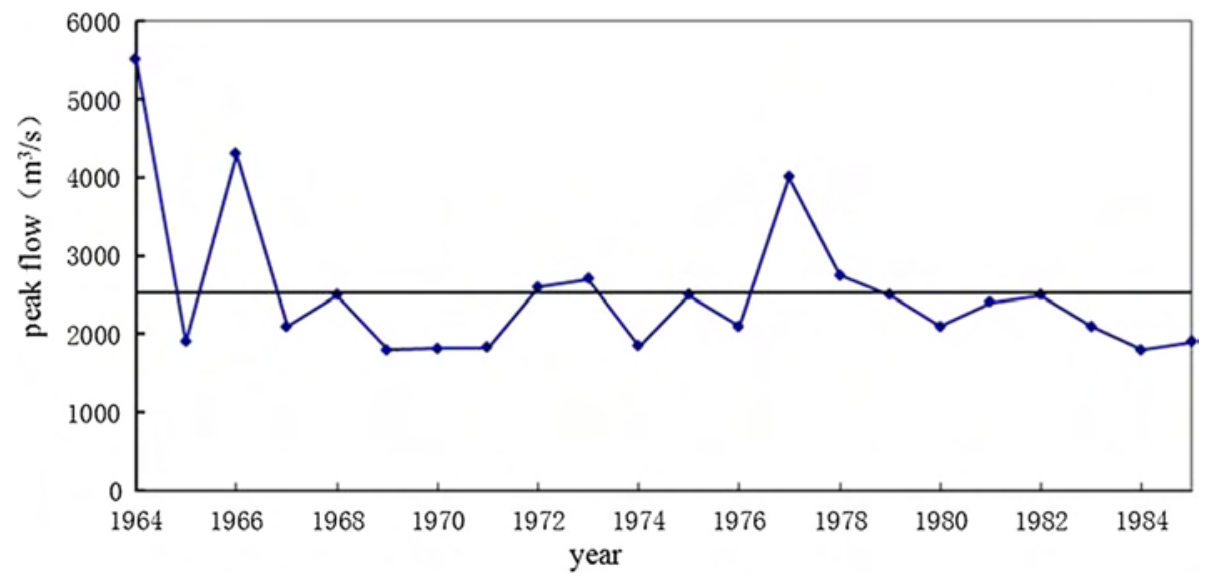

Figure 7. Peak flow of floods at Zipingpu hydrologic station in the upper Minjiang River.

Table 1. Frequency calculation table of the peak flow at Zipingpu hydrological station.

\begin{tabular}{|c|c|c|c|c|}
\hline Year & $\begin{array}{l}\text { Peak flow } \\
\left(\mathrm{m}^{3} / \mathrm{s}\right)\end{array}$ & $\begin{array}{c}\text { Peak flow } \\
\text { (descending order) }\end{array}$ & $\begin{array}{l}\text { Sequence } \\
\text { no. }\end{array}$ & $\begin{array}{l}\text { Frequency } \\
\qquad(\mathrm{P})\end{array}$ \\
\hline 1964 & 5500 & 5500 & 1 & 4.5 \\
\hline 1965 & 1900 & 4300 & 2 & 9.1 \\
\hline 1966 & 4300 & 4000 & 3 & 13.6 \\
\hline 1967 & 2100 & 2750 & 4 & 18.2 \\
\hline 1968 & 2500 & 2700 & 5 & 22.7 \\
\hline 1969 & 1800 & 2600 & 6 & 27.3 \\
\hline 1970 & 1820 & 2500 & 7 & 32.8 \\
\hline 1971 & 1830 & 2500 & 7 & 32.8 \\
\hline 1972 & 2600 & 2500 & 7 & 32.8 \\
\hline 1973 & 2700 & 2500 & 7 & 32.8 \\
\hline 1974 & 1850 & 2400 & 11 & 50 \\
\hline 1975 & 2500 & 2100 & 12 & 54.5 \\
\hline 1976 & 2100 & 2100 & 12 & 54.5 \\
\hline 1977 & 4000 & 2100 & 12 & 54.5 \\
\hline 1978 & 2750 & 2100 & 12 & 54.5 \\
\hline 1979 & 2500 & 1900 & 16 & 72.7 \\
\hline 1980 & 2100 & 1900 & 16 & 72.7 \\
\hline 1981 & 2400 & 1850 & 18 & 81.8 \\
\hline 1982 & 2500 & 1830 & 19 & 86.4 \\
\hline 1983 & 2100 & 1820 & 20 & 90.9 \\
\hline 1984 & 1800 & 1800 & 21 & 95.5 \\
\hline
\end{tabular}

(figure 8). Here we summarize the floods after the Wenchuan earthquake in the upper Minjiang River (Ding et al. 2013a, 2014b).

\subsection{Post-seismic floods at Yingxiu town on August 13-18, 2010 (Ding et al. 2013)}

On August 13 and 18 of 2010, heavy rainfall attacked Yingxiu town in the upper Minjiang River (table 2, figures 8 and 9), and triggered a mass of flood disaster in Yingxiu town. According to data at the Yingxiu meteorological station, the total rainfall on August 12 in Yingxiu town was $19.9 \mathrm{~mm}$. On August 13, the daily cumulative rainfall was $126.8 \mathrm{~mm}$, and the maximum hourly rainfall intensity was $32.2 \mathrm{~mm} / \mathrm{hr}$. On August 14, the cumulative rainfall was $23.4 \mathrm{~mm}$. The total rainfall amounted to $162.1 \mathrm{~mm}$, and the maximum hourly rainfall intensity was $16.4 \mathrm{~mm} / \mathrm{hr}$. So a flash flood and debris flow broke out in the Hongchun Gully. The 


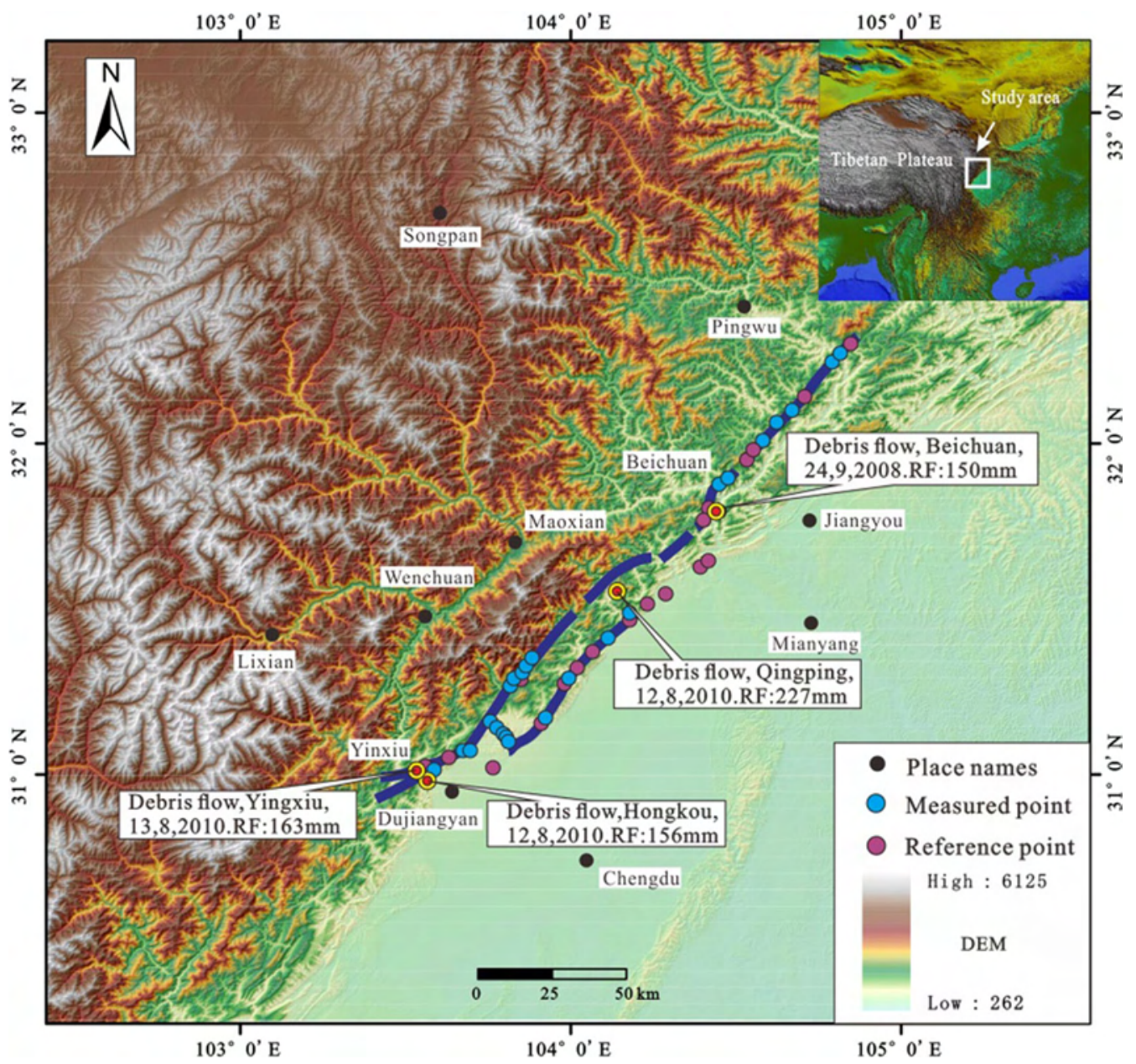

Figure 8. The distribution of floods and debris flows after Wenchuan earthquake in Longmen Shan region.

debris flow destroyed roads and houses, blocked the $120-\mathrm{m}$ wide river channel, and a barrier dam with an average height of $7 \mathrm{~m}$ (Tang et al. 2011). When the huge barrier body burst, the resulting powerful flood destroyed the Road 213 and the Dujiangyan-Wenchuan expressway. Because the barrier dam blocked the left river course, its course was changed which caused the flood to rush into Yingxiu town, destroying parts of the town which had just been reconstructed after the Wenchuan earthquake (Xiang et al. 2010).

\subsection{Post-seismic floods Longchi town on August 13-18, 2010}

On August 13, 2010, heavy rainfall attacked Longchi town in Dujiangyan. According to precipitation data at the Chaguan meteorological station (table 2, figure 10), total rainfall was $156.9 \mathrm{~mm}$, and maximum hourly rain intensity was $75 \mathrm{~mm} / \mathrm{hr}$ from August 13 to 14. At 16:00, large-scale debris flow formed. At 17:40, the debris flow changed into a flood flow (figure 10). The total August 18 rainfall was $252.2 \mathrm{~mm}$, and maximum hourly rain intensity was $69 \mathrm{~mm} / \mathrm{hr}$ from August 18 to 19. At 20:00, a flash flood and debris flow formed (figure 10). This post-seismic flood trapped nearly 800 persons, mortality was 1 , with 12 were missing, 137 houses collapsed or destroyed (Ding et al. 2013a).

\section{Mechanism of post-seismic floods in the upper Minjiang River}

\subsection{The heavy rainfall is controlled by the orographically-enhanced precipitation}

The upper Minjiang River is a typical high- and steep-slope mountain river basin. The distribution of precipitation is mainly affected by warm air of the southeast monsoon and relief. Because the east side of the Longmen Shan is windward, the warm air of the southeast monsoon rises and 


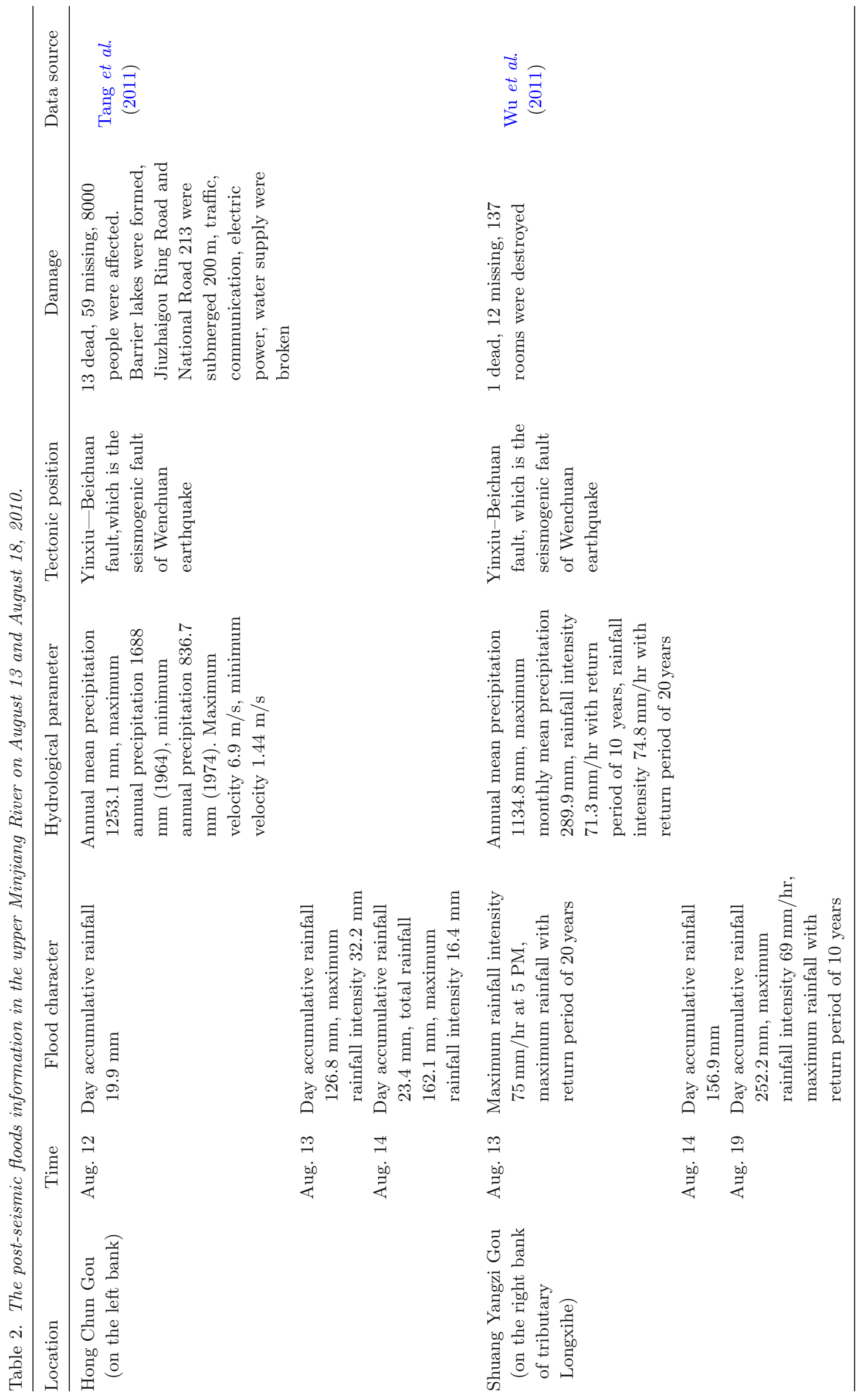




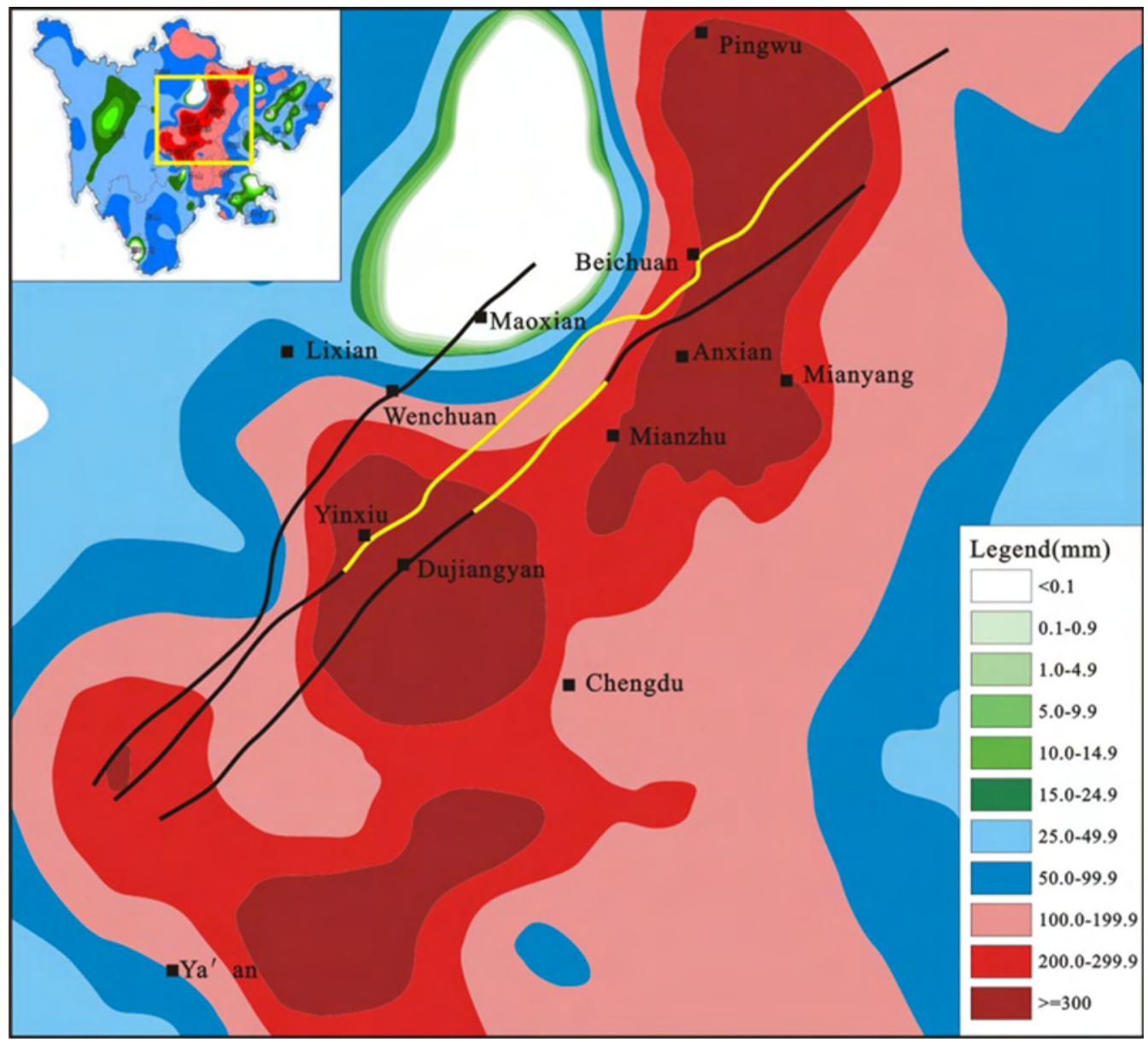

Figure 9. Sichuan precipitation maps, in mid-August, 2010 (Yan et al. 2011). (1. The orographic precipitation outbreak many times in earthquake disaster area after the earthquake in 2008, and the most serious storms occurred on August 13 of 2010; 2. Heavy rains coincide with the earthquake rupture zone).

orographically-enhanced precipitation is formed, as in figure 11 ( $\mathrm{Li}$ et al. 2014). So the rainfall center shall be formed at piedmont region of Longmen Shan. Therefore, heavy rain occurs frequently in the upper Minjiang River, which causes the storm floods with high frequency, large magnitude, and serious disaster (Ding et al. 2013c).

\subsection{Wenchuan earthquakes provide the conditions} for the development of post-seismic flood (Ding et al. 2013a)

In the region, the strong rainstorm area roughly coincides with the Yingxiu-Beichuan fault zone as in figure 12 (Densmore et al. 2007; Li et al. 2010, 2011; Zhou et al. 2011). The Wenchuan earthquake on May 12, 2008 induced a significant collapse and landslide, providing important sources of unconsolidated solids for the formation of debris flow (figure 12) and the occurrence of strong rainstorm can easily trigger debris flow and post-seismic flood. The Wenchuan earthquake of 2008 caused the collapse, landslide, debris flow and other secondary disasters, which led to serious damage of forest in the area (Tang et al. 2012; Parker et al. 2011; Li et al. 2014). According to preliminary estimates in the zone, damaged forest is 89326.31 $\mathrm{hm}^{2}$ (Huang et al. 2009). The vegetation coverage decreasing by $20 \%$ in the core area of the earthquake (Bao 2008).

Flood kinetics are generally inversely proportional with vegetation cover, that is to say, the decreasing vegetation coverage rate has a direct impact on the increasing frequency of flood. In addition, after the Wenchuan earthquake, soil erosion is significantly greater than that before earthquake. The average soil erosion modulus before the earthquake is $3703 \mathrm{t} /\left(\mathrm{km}^{2} \mathrm{a}\right)$ and increased to $4604 \mathrm{t} /\left(\mathrm{km}^{2} \mathrm{a}\right)$ (Deng et al. 2008) after the earthquake, and the soil erosion intensity amplitude is amounted to $25 \%$. The average annual amount of soil erosion is $4.98 \times 10^{8} \mathrm{t}$ before the earthquake, 

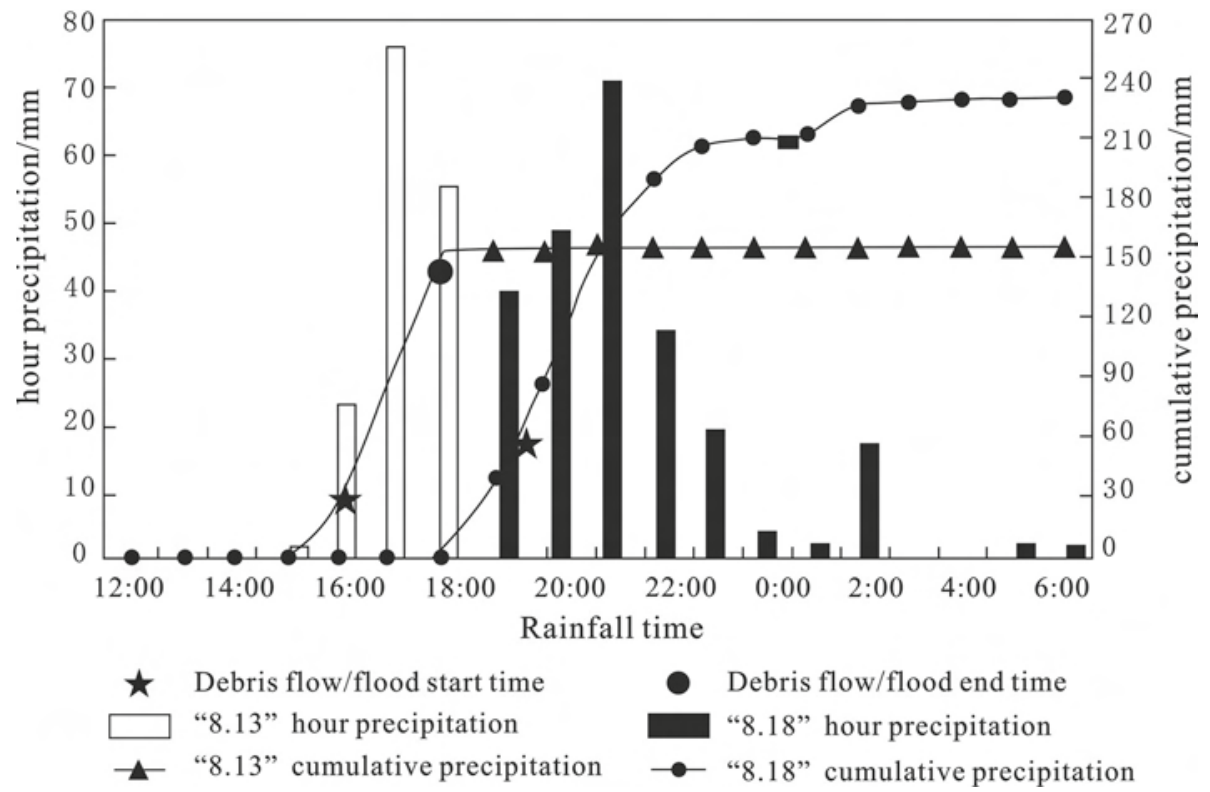

Figure 10. Rainfall process on August 13-18, 2010 at Longchi Town (Ma et al. 2011).

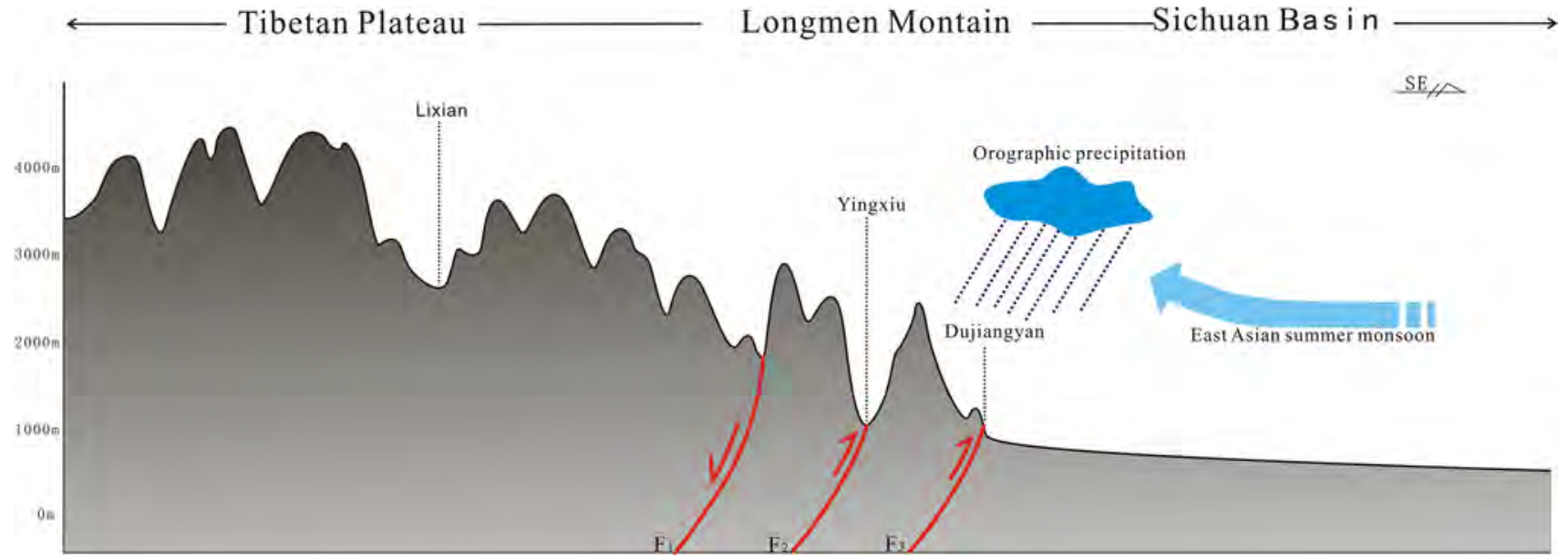

Figure 11. The orographically-enhanced precipitation on Longmen Shan (Li et al. 2014).

while that is $6.87 \times 10^{8} \mathrm{t}$ after the earthquake. Because of the increase of soil erosion, the flood sediment concentration increased. These data suggest that Wenchuan earthquake caused a decline in the efficiency of conservation of forest and soil erosion, so most of precipitation was not absorbed and retained, but instead formed runoff. These phenomena in turn increased the maxima of flood flow, peak, and sediment concentration (Ding et al. 2013a, 2014b).

\subsection{Heavy rainfall is the trigger to post-seismic floods}

No flood occurred in the upper Minjiang River in 2008 and 2009 after Wenchuan earthquake, which leads some people think that the post-seismic flood would not occur. The reason is that in the period from 2008 to 2009, precipitation is within $834.8-1222.4 \mathrm{~mm}$, which belongs to the category of historic relatively dry years (Ding et al. 2013a).

But in 2010, serious flood attacked the Longmen Shan area. The rainfall was $2545.8 \mathrm{~mm}$, and the rainfall was especially concentrated in August. The precipitation was $507.2 \mathrm{~mm}$, which is $239 \mathrm{~mm}$ more than the average annual precipitation (figure 10). Due to this heavy rainfall, a large amount of loose material caused by the Wenchuan earthquake could be transported into the river leading to the outbreak of the post-seismic flood. Therefore, heavy rainfall is causation trigger for post-seismic floods (Ding et al. 2013a). 


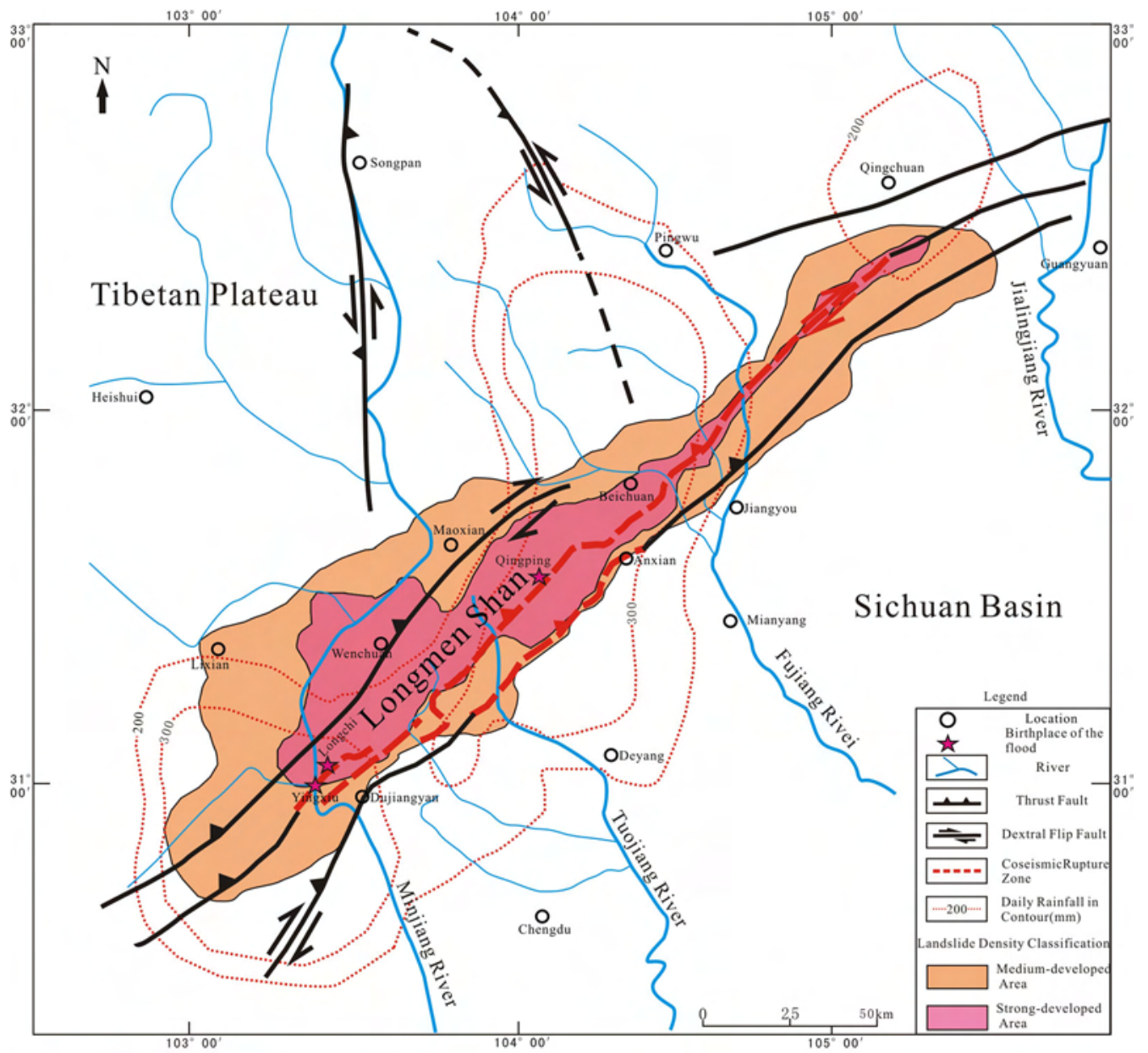

Figure 12. The distribution of rainfall and debris flows in the Middle-August of 2010 (Li et al. 2014).

For the Wenchuan earthquake post-seismic floods, we propose the following causation chain of events and process: heavy rainfall supersaturates unconsolidated debris, gravity-induced mass-flow of debris, clearance of debris out of the gully into the river, and formation of barrier lakes. The accumulation of hydraulic back-pressure and over-flow breaches and bursts the barrier dam at its weakest point. The ensuing high-velocity flood impacts and destroys post-earthquake construction. After the Wenchuan earthquake, strong rainstorm weather increased, especially in the main flood season, such as the 2010 August 13 and 18 heavy rainfall (figure 10; Ding et al. 2013a, 2014a). The high intensity concentrated in a short period of time triggered serious post-seismic flood disaster. The criterion of rainfall-caused floods was 80 $100 \mathrm{~mm}$, and rainfall intensity was $30-50 \mathrm{~mm} / \mathrm{hr}$ before the earthquake in Longmen Shan area (Ding et al. 2013a, 2014b). After the earthquake, the intensity that resulted in flooding was reduced to $16.4 \mathrm{~mm} / \mathrm{hr}, 45-67 \%$ less than that before the
Wenchuan earthquake (Tang et al. 2011). Therefore, the criterion of rainfall-caused floods also has been reduced significantly after the Wenchuan earthquake. In addition, after the Wenchuan earthquake, flood volume and frequency increases in the upper Minjiang River (Tang et al. 2012).

\subsection{Channel aggradations and outburst of barrier lakes aggravate the abruptness and destructiveness of post-seismic flood}

Wenchuan earthquake induced significant collapses and landslides, causing a large amount of loose material to accumulate at foothills and mountain terraces. After heavy rainfall, those loose materials are transported into rivers which would occupy the channel space and reduce the capacity to deliver water during flooding (figure 13), and exacerbate the destructiveness of flash flood (Korup 2004; Li et al. 2014). For example, in 2010, there was largescale debris flow outburst in Shenxigou of Baisha River catchment. The debris flowed into channel 


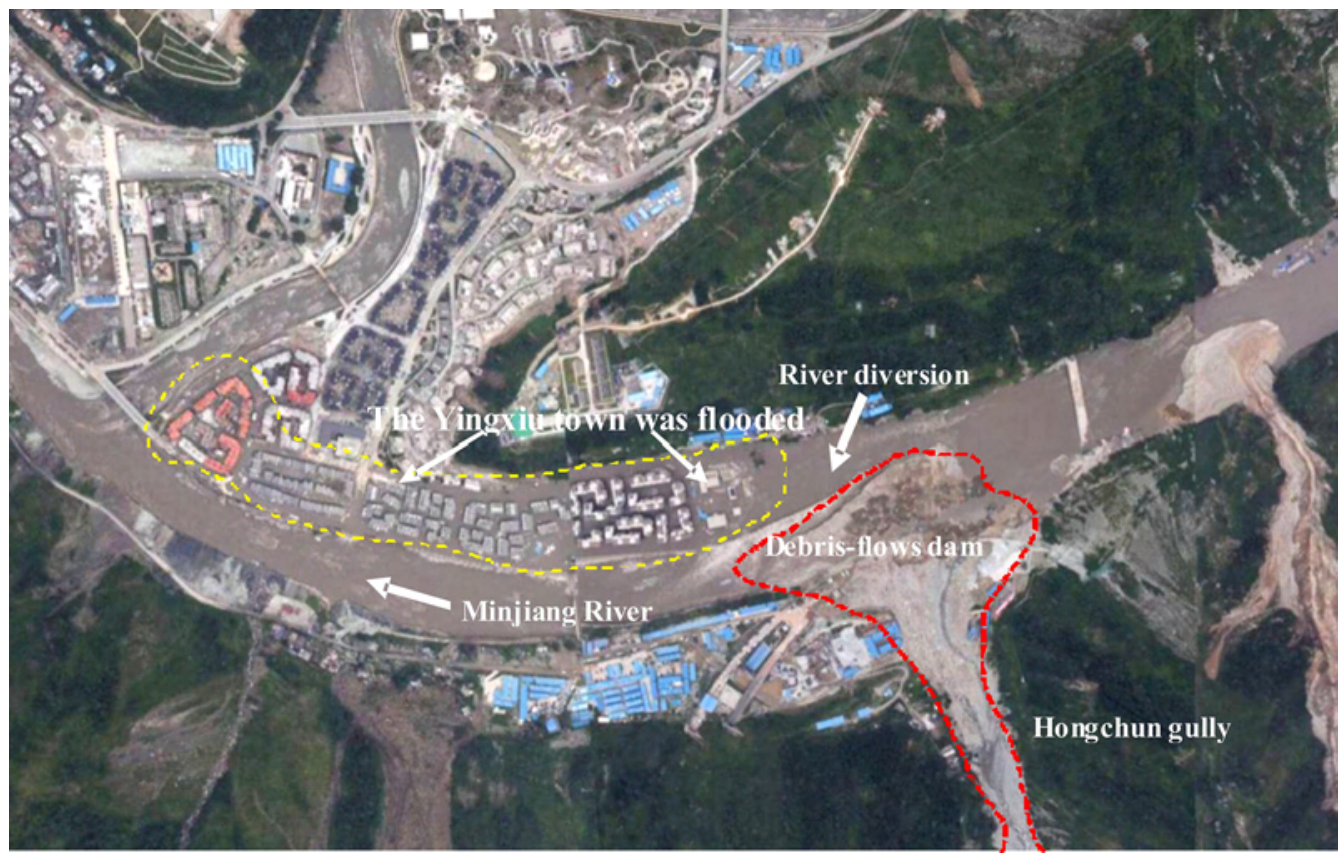

Figure 13. Debris flows on August 13, 2012 Hongchun Gully (aerial photograph from the Sichuan Geological Environment Monitoring Station; Li et al. 2013).

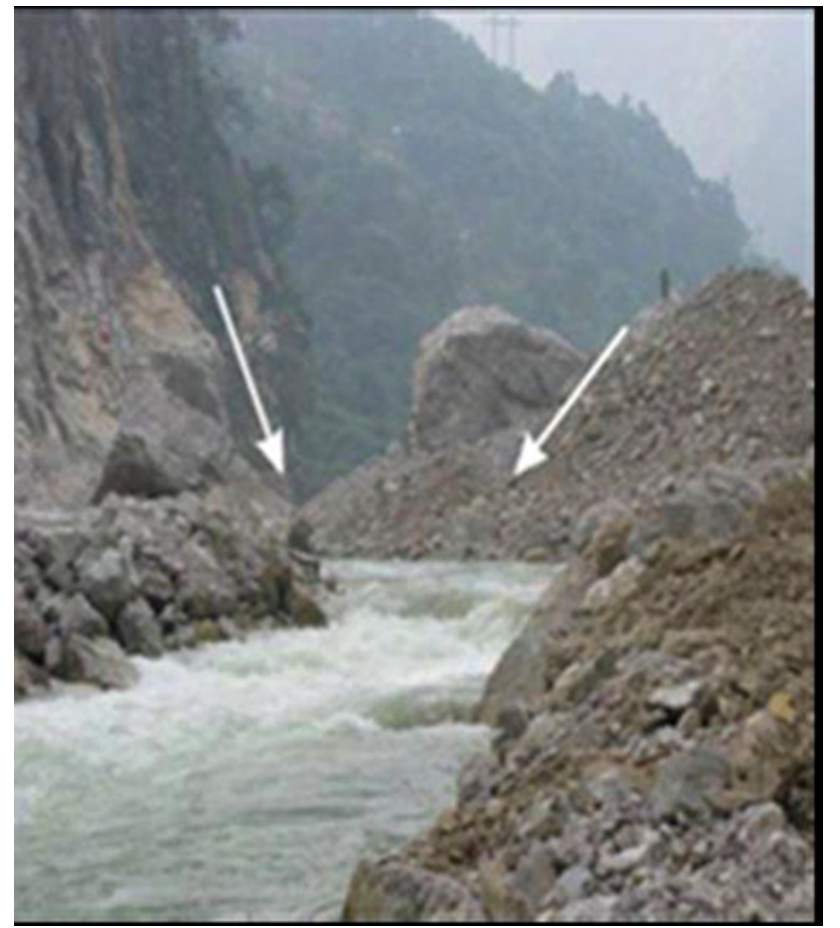

Figure 14. Debris flowed into channel of Baisha River.

of Baisha River and induced larger flood disaster (figure 14).

The seismic landslides block river course and the barrier outburst exacerbate emergency and destructiveness. The Wenchuan earthquake prompted unstable rock mass collapses, landslide, river blockage, and formation of barrier lakes.
There are numerous tributaries and appropriate locations to form barrier lakes in the area. So when strong rainstorm occurs, floods rapidly concentrate, and when the flood volume is more than storage ability of the barrier lake, overflow is generated, causing the collapse of the barrier weir, formation of post-seismic flood, and serious flood disaster.

For example, in 1933, a magnitude of 7.5 earthquake hit Diexi. Landslides ensued blocked the main course of Minjiang River and branch river courses, with more than 10 barrier lakes forming. Forty-five days after the earthquake, the Diexihaizi barrier lake burst and caused a series of down-stream barrier lakes break. The flood affected $250 \mathrm{~km}$ downstream, killed 20,000 people and destroyed most villages and towns of Maoxian, Wenchuan and Guan county (now Dujiangyan city), resulting in one of the serious historic flood disasters in China and the world. While the earthquake itself killed nearly 7000 people (Jiang et al. 1989), the geo-hazards generated by post-seismic events may be far more serious than the earthquake itself.

\section{Conclusions}

Based on the correlation among precipitation, runoff and floods in 2010 in the upper Minjiang River, post-seismic floods caused by heavy rainfall 
after Wenchuan earthquake have been studied in this paper. Some conclusions are summarized as following: (i) The Wenchuan earthquake provides the essential conditions for the post-seismic floods. The upper Minjiang River just located at the epicenter of Wenchuan earthquake, shows the post-seismic disaster chain: earthquake-collapselandslide-debris flows-floods; (ii) the heavy rainfall controlled by the orographically-enhanced precipitation is one important factor inducing postseismic floods, and (iii) river channel aggradations and outburst of barrier lakes aggravate the abruptness and destructiveness of post-seismic flood. Research results show that, Wenchuan earthquake caused plenty of loose material, and frequency of post-seismic floods caused by heavy rainfall shall increase. The next 5 -10years will be the crest time of post-seismic floods in the area. Therefore, detailed investigation and cataloging work should be carried out urgently on quake barrier lakes caused by Wenchuan earthquake, and rainstorm real-time monitoring and warning system should be established. Post-seismic floods disaster prevention and control engineering should be carried out, and conference communication should be strengthened with large and mediumsized hydropower stations in the upper Minjiang River. Those will be beneficial to improve flood forecast accuracy and scientific and foresight of decision-making in the flood control and disaster mitigation.

\section{Acknowledgements}

This study was sponsored by the Natural Science Foundation of China (Grant Nos. 41602306, 41402 159, 41340005, 41372114), the Research Project of Sichuan Education Department (No. 14ZB0072), and the Research Project of Sichuan Province and Technology Development. We are grateful to the Bureau of Hydrology and Water Resources Survey in Sichuan province for the data. We are thankful to Prof. Cao Shuyou for the help and suggestions during the preparation of this manuscript. We are also thankful to our reviewers for their useful suggestions.

\section{References}

Bao W K 2008 Ecological degradation and restoration and reconstruction countermeasures for severe calamity regions in Wenchuan earthquake in Sichuan; Sci. Techno.
Disa. Relf. 23(4) 324-328 (in Chinese with English abstract).

Cui P, Wei F Q and Chen X Q et al. 2008 Geo-hazards in Wenchuan earthquake area and countermeasures for disaster reduction; Sci. Techno. Disa. Relf. 23(4) 317323 (in Chinese with English abstract).

Deng Y L, Meng Z X and Wang Y K et al. 2008 Study on soil erosion changes and controlling strategy in the Minjiang River valley; J. Soil Water Conserv. 22(5) 55-60 (in Chinese with English abstract).

Densmore A L, Li Y and Richardson N J et al. 2010 The role of late Quaternary upper-crustal faults in the 12 May 2008 Wenchuan Earthquake; B. Seismol. Soc. Am. 100(5B) 2700-2712.

Densmore A L, Ellis M A and Li Y et al. 2007 Active tectonics of the Beichuan and Pengguan faults at the eastern margin of the Tibetan Plateau; Tectonics 26(4)113127.

Ding H R, Li Y and Ma G W 2013a Post-seismic floods after the 2008 Wenchuan (Ms 8.0) earthquake in the Minjiang River, Sichuan; Acta Geol. Sin-Engl. 87 629-630.

Ding H R, Li Y and Yan L et al. 2013b The Jianjiang drainage pattern in Longmenshan area and its response on Wenchuan earthquake; Quat. Sci. 4 802-811 (in Chinese with English abstract).

Ding H R, Li Y and Yan L et al. 2013c Influences of disaster chain driven by Wenchuan earthquake on sediment discharge in upper reaches of Minjiang River, Sichuan, China; J. Chengdu Univ. Techno. (Sci. Technol. Ed.) 40(6) 712-720 (in Chinese with English abstract).

Ding H R, Li Y and Ni S J et al. 2014a Increased sediment discharge driven by heavy rainfall after Wenchuan earthquake: A case study in the upper reaches of the Min River, Sichuan, China; Quat. Int. 333 122-129.

Ding H R, Li Y and Ma G W et al. 2014b Study on sediment discharge increase caused by Wenchuan earthquake landslide and heavy rainfall in the upper reaches of the Min River; J. Sichuan Univ. (Eng. Sci. Ed.) 46(3) 49-55 (in Chinese with English abstract).

Huang G Z, Liu X D and He F 2009 Earthquake damaged vegetation and its restoration and reconstruction countermeasures in the upper reaches of Minjiang River; $J$. Sichuan Fst. Sci. Techno. 30(3) 95-99 (in Chinese with English abstract).

Jiang Z X, Xu J T and Li T H 1989 Post-seismic flood of Diexi in 1933 and flood damage of Minjiang in 1986; J. Catastrophol. 4 63-67 (in Chinese with English abstract).

Korup O 2004 Landslide-induced river channel avulsions in mountain catchments of southwest New Zealand; Geomorphology 63 57-80.

Li Y, Li B and Steffen D et al. 2006 Provenance analysis and drainage evolution in late cenozoic Chengdu Basin on eastern margin of Tibetan plateau; Acta Sedim. Sin. 24(3) 309-320 (in Chinese with English abstract).

Li Y, Li B and Zhong R J et al. 2007 The quantitative correlation between denudation volume and sedimentary flux in the denudation-accumulation system: Examples from Minjiang River drainage system; Acta Sedim. Sin. 332 343 (in Chinese with English abstract).

Li Y, Huang R Q and Zhou R J et al. 2010 The Ms 8.0 Wenchuan earthquake and co-seismic river response; $J$. 
Sichuan Univ. (Eng. Sci. Ed.) 42(5) 20-33 (in Chinese with English abstract).

Li Y, Zhou R J and Densmore A L et al. 2011 Spatial relationships between surface ruptures in the Ms 8.0 earthquake, the Longmen Shan region, Sichuan, China; J. Earthq. Tsunami. 5(4) 329-342.

Li Y, Yan Z K and Zhou R J et al. 2013 Surface process and fluvial landform response to the Ms 8.0 Wenchuan earthquake, Longmenshan, China; J. Earthq. Tsunami. $7(5) 26 \mathrm{p}$.

Li Y, Zhou R J and Zhao G H et al. 2014 Tectonic uplift and landslides triggered by the Wenchuan earthquake and constraints on orogenic growth: A case study from Hongchun Gully, Longmen Mountains, Sichuan, China; Quat. Int. 349 142-152.

Lin C W, Liu S H and Lee S Y et al. 2006 Impacts on the Chi-Chi earthquake on subquent rain-induced landslides in central Taiwan; Eng. Geol. 86 87-101.

Luo Z C 2011 Cause analysis of "8.13" flood disaster in Xihe; Water Conserv. Sci. Techno. Econ. 17(3) 70-73 (in Chinese with English abstract).

Ma Y, Yu B and Wu Y F et al. 2011 Research on the disaster of debris flow of Bayi Gully, Longchi, Dujiangyan, Sichuan; J. Sichuan Univ. (Eng. Sci. Ed.) 43(1) 92-98 (in Chinese with English abstract).

Parker R N, Densmore A L and Rosser N J et al. 2011 Mass wasting triggered by the 2008 Wenchuan earthquake is greater than orogenic growth; Nat. Geosci. 4(7) 449-452.

Tang C, Li W L and Ding J et al. 2011 Field investigation and research on giant debris flow on August 14, 2010 in Yingxiu town, epicenter of Wenchuan earthquake; Earth Sci.-J. China Univ. Geosci.36(1) 172-180 (in Chinese with English abstract).

Tang C, Van Aschtwj and Chang M 2012 Catastrophic debris flows on 13 August 2010 in the Qingping area, southwestern China: The combined effects of a strong earthquake and subsequent rainstorms; Geomorphology 139 559-576.

Tie Y B and Tang C 2011 Response characteristics between Wenchuan earthquake and the rainfall induced debris flow in Beichuan Country, Sichuan; J. Catastrophol.26(4) 7375 (in Chinese with English abstract).

Wang G X and Cheng G W 2008 Some thoughts on hydrology and water environment problems in reconstruction in earthquake-hit areas; J. Mt. Sci. 26(4) 385-389 (in Chinese with English abstract).

Wang J, Jin Z D and Hilton G R et al. 2015 Controls on fluvial evacuation of sediment from earthquake-triggered landslides; Geology 43(2) 115-118.

Wu Y F, Yu B and Ma Y et al. 2011 Debris flow of Shuangyangzi gully, Dujiangyan City in Wenchuan earthquake area; Sci. Soil Water Conserv. 9(3) 13-17 (in Chinese with English abstract).

Xiang L Z, Cui P and Fang H 2010 Mechanism of disaster chain after earthquake and the impact to urban reconstruction in Wenchuan earthquake area; J. Catastrophol. 25(S0) 278-281 (in Chinese with English abstract).

Xu L X 2006 The upper reach of the Min Jiang River runoff analysis and its forecast; $\mathrm{PhD}$ thesis, Sichuan University (in Chinese with English abstract).

Xu M Z, Wang Z Y and Shi W J et al. 2010 Mountain disaster chain induced by the Wenchuan earthquake in the Huoshiguo Gorge; J. Tsinghua Univ. 50(9) 1338-1341 (in Chinese with English abstract).

Yan Z K, Li Y and Huang R Q et al. 2011 Effects of Wenchuan earthquake on sediments transport of river systems in Longmen Shan area; Chinese J. Nat. 33(6) 337-340 (in Chinese with English abstract).

You Y, Chen X Z and Liu J F 2011 '8.13' Extra large debris flow disaster in Wenjia gully of Qingping Township, Mianzhu, Sichuan Province; J. Catastrophol. 26(4) 68-72 (in Chinese with English abstract).

Zhang Q D 2006 A study on the relation of between runoff and sediment variations and deforestation in the upper of Minjiang River; Master thesis, Southwest University (in Chinese with English abstract).

Zhou R J, Li Y and Densmore A L et al. 2011 The strong motion records of the Ms 8.0 Wenchuan Earthquake by the digital strong earthquake network in Sichuan and the neighboring region; J. Earthq. Tsunami. 5(4) 343361. 